\title{
Disruptive strangeness or domesticated exoticism? Some challenges of cultural translation in the Polish rendition of Fury by Salman Rushdie
}

\begin{abstract}
The unfolding hybridisation of cultures calls for a culture-oriented approach to translation that could respond to the needs and expectations of contemporary readership. The present paper is devoted to the concept of the cultural turn in translation studies and its practical implications on actual translations of contemporary literary works. To illustrate the complexities of translating cultural elements, the Polish translation of Fury reflecting the usual Rushdian blend of voices, plots, multi-cultural hybrid and culture references is used. The paper seeks to exemplify and discuss choices made by the translator striving to acquaint the target text reader with the complex universe of the novel to the similar extent as experienced by the source text reader. The principal strategy adopted by the Polish translator might be labelled as domesticated exoticism.
\end{abstract}

Keywords: cultural translation, domesticated exoticism, Fury by Salman Rushdie, contemporary literary translation, translation strategies.

\section{The concept of cultural translation}

Over the last decades, we have seen various translation scholars and practitioners articulate with force a strong need for a new approach to translation that in the age of growing hybridisation of cultures should be adjusted to expectations of contemporary readership. This cultural approach in Translation Studies or cultural turn, as the phenomenon was originally referred to by Mary Snell-Hornby (1990), is associated with the landmark work of Susan Bassnett and André Lefevere as editors, Translation, History and Culture, first published in 1990. It put forward a major change in the perspective, with linguistic approach serving but as a starting point to develop a culture-based standpoint:

Now the questions have changed, the object of study has been redefined, what is studied is the text, embedded within its network of both source and target cultural signs and in this way Translation Studies has been able to utilize the linguistic approach and move out beyond it. (Bassnett \& Lefevere 1990: 12)

As emphasised by Dorota Urbanek, their volume shifted the focus from language to culture, from translation regarded as operation on texts towards translation seen as operation on cultures (Urbanek 2010: 156). Since this potent paradigm shift, the

1 Address for correspondence: Maria Curie-Sklodowska University, Faculty of Philology, Institute of Modern Languages and Literatures, Pl. Marii Curie-Skłodowskiej 4a, 20-031 Lublin, Poland. E-mail: agnieszka.stawecka-kotula@mail.umcs.pl 
perception of both the translation process itself and its product has been shaped by the emphasis on translation between cultures, respect for alterity and communication seen as cross-cultural dialogue. Basil Hatim recapitulates the cultural turn in translation by acknowledging that: "the general trend in translation studies is clearly towards cultural rather than linguistic transfer. This entails that the process be viewed not as a transcoding of products but as a process of communication" (Hatim 2001: 61).

As many scholars, including David Katan, argue, to achieve successful intercultural communication, a dialogue between two or more cultures needs to be initiated by the translator who facilitates understanding and acts a "cultural mediator" (Katan 1996: 3). The mediatory function of translation in the context of cross-cultural dialogue is discussed at length by Bożena Tokarz. According to Tokarz, internal connections between language, culture and the individual speaking become particularly visible in artistic translation as it is a creative process fulfilling a 'mediatory, informative and supplementary function'2 (Tokarz 2006: 10). The mediatory function of translation enables the two cultures to come into contact and it is only possible when the balance between "the known" and "the unknown" is maintained. Tokarz observes that "the otherness" manifests itself at the level of lexis, morphology, syntax and style. Thus, as she argues, the occurrence in the source text (ST) of, among others, proper names and functional variants of language ${ }^{3}$ should be preserved in the target text (TT). However, as the scholar notes, some linguistic phenomena ${ }^{4}$ require individual solutions of the translator, who cannot violate the accepted linguistic norms. Hence the translator is often obliged to employ different linguistic structures than the ones used in the TT and as a cultural mediator has to make rational choices and to compromise (Tokarz 2006: 10-11). In her paper, Tokarz makes a fundamental assumption that unlike some translations performing colonising function by subordinating other language, culture and thought to their own, cultural translation acquaints the reader with another culture, a different set of beliefs, broadens their mental, aesthetic and intellectual horizons, teaches new sensibility and inspires them to challenge the existing culture-specific stereotypes (Tokarz 2006: 14). In other words, to avoid the colonising effect and to maintain the dialogue between two cultures, the translator is obliged to respect the otherness.

\section{Fury by Salman Rushdie as a cultural translation challenge}

In the light of the above assumption, the obvious questions arise as to what extent the translator is both able and allowed to preserve the otherness and traces of the source culture (SC) in the target text and what strategies or procedures best serve this purpose. To tackle these questions, it seems perfectly reasonable to use an existing rendition of a culture-loaded literary work that could illustrate some of the potential challenges and traps awaiting the translator. In this respect, one of works worth analysing is Fury by the India-born British author, Salman Rushdie. Rushdie's multifaceted identity and unique literary style coincide closely with the ideology behind cultural translation.

\footnotetext{
${ }^{2}$ All translations are mine.

${ }^{3}$ Here, Tokarz refers to such functional variants of language as colloquial, official, sloppy, literary and professional language.

${ }^{4}$ To quote Tokarz, those are polysemous expressions, neologisms, idiomatic expressions, proverbs, forms of address and wordplay.
} 
Often labelled as a postcolonial author and the "other" voice in English literature, Rushdie joins a host of contemporary British writers whose cultural backgrounds come from former colonies and who, to quote Tim Woods:

[...] produce fictions that interrogate not only the colonial legacies in their cultural homelands, but also question and explore the implications of multiculturalism in the UK, or the cultural, social and political effects of being non-British and non-white within a contemporary pluralist society (Woods 2004: 741).

However, Rushdie himself prefers to be referred to as "a sort of multinational hybrid," sharing the sense that many writers have of belonging to both cultures, which, as Homi Bhabha argues, subverts the narratives of colonial power and dominant culture (Bhabha 1994: 85). Unfortunately, the infamous fatwa, imposed on the author in 1989 by Ayatollah Khomeini following publication of his fourth novel, The Satanic Verses, proves somehow that different vantage points and cultural dissimilarities can be the reason for grave misunderstandings and that the process of merging and intercultural dialogue is still deeply flawed.

Most of Rushdie's novels are reflective of the metafictional trend in contemporary literary writing. The author is well known for intermingling historical facts with fictitious narration, claiming thus the right to interpret history as a subjective selection of unascertainable memories and not so much as a series of verifiable facts. His writings abound in intertextuality, cross-referenced names, vivid images and allusions to both classical works of art and mass entertainment creations. According to Michael Wood, other features of Rushdie's style are "garrulousness," "melodrama," "hyperbole" and "writing in pictures" (Wood in Di Mauro 2000: 117). Paired with extensive commentaries, lengthy digressions, and erudite reflections found in Rushdie's works, the above characteristics of his style require both a very attentive and patient reader, let alone the translator endeavouring to elicit the same response in the TT reader.

Having in mind the usual oriental setting of Rushdie's novels, one may be surprised by the distinctiveness of Fury with most of the novel set in New York, viewed through British-Indian lenses of the protagonist and the main narrator of the story in one - Malik Solanka. This fifty-five-year-old Indian professor of philosophy and a historian of ideas turned a sophisticated doll maker and, eventually, a Web designer is torn apart by his internal struggle. Mysterious, unaccountable feelings of rage disrupt his otherwise peaceful existence. When his obsessions escalate into an outright fit of fury and a narrowly prevented act of violence against his perfect wife and his beloved son, he decides to flee his comfortable London life to seek refuge and much desired redemption in New York. In the novel, the city is viewed as a potent symbol of America that "insults the rest of the planet" (Rushdie 2002: 6), represents imperial wealth and excess, houses debasement of moral values and encapsulates contemporary vanities and fears. It therefore proves to be a perfect setting for Rushdie's central theme of the book - fury which in narrator's own words "drives us to our finest heights and coarsest depths" (Rushdie 2002: 30). The main protagonist's fate is intertwined with the one of Greek goddesses of vengeance, the Erinnyes, i.e. the Furies. They are embodied in three women of Solanka's adult life - his wife, Eleanor, and his two New York lovers, the Serbian Mila and the Indian Neela. Regardless of whether this literary depiction of furia is naively overromantic and brought to an unconvincing denouement for some, it accurately 
reflects typically Rushdian inventive blend of plots, voices, views, digressions, tales, myths, allegories, puns, magic realism, multi-cultural hybrid and historical and pop culture references.

As such this multifaceted universe of Fury constitutes a real challenge for the translator wishing to render the novel into Polish. Jerzy Kozłowski took up the challenge and strived to tackle most of the translation problems of the source text. The final outcome, the Polish rendition of Fury, is definitely worth scrutinising to investigate the degree to which the intricate network of intertextual relations and polyphonic diversity present in the source text has been preserved in the target text and to discover what and why has been lost.

\section{Various approaches to rendition of cultural elements: different degrees of exoticism}

The primary questions to be asked while approaching the cultural elements present in the source text are whether they constitute authentic realia and whether they exist in translator's native context. The answers to these questions should determine translator's decisions about solutions to be adopted. The cultural perspective from which the translation of Fury should be analysed entails that the process be viewed also with reference to the already deep-rooted in most translation scholars' minds notions of foreignisation and domestication, popularised by Lawrence Venuti. The foreignisation/domestication model, as Nathalie Ramière notes, "has been acclaimed as a powerful tool to conceptualise the interface between the source culture - seen as the 'Self' - and the target culture (TC) - seen as the 'Other' - but has also sparked wide debate in the field" (Ramière 2006). Different terms such as "naturalisation," "assimilation," or "exotisation" have been coined later on to name the two extremes of the translation spectrum (Ramière 2006). To untangle this fundamental issue, it seems

pertinent to consider Piotr Kwieciński's interesting view on the foreignisation/domestication scale (F/D scale). Kwieciński perceives it not as an objective, binary and static division, but as a gradable scale highly dependent on skopos, co-text, context and individual subjective sensibilities. He offers his own definition of foreignisation as "a translation strategy which results in a target-text profile that is disruptive, alien and/or obscure vis-à-vis prevailing target-culture norms," while domestication is defined by him as "the accommodation of the target text to established TL/TC norms and conventions" (Kwieciński 2004: 30). Having modified Venuti's definitions, Kwieciński suggests that the F/D strategies, together with all the intermediate grades of the scale, are not related exclusively to the choice of translation procedures ranging from borrowing to cultural substitution. Quite the opposite, in his work, he proves that the F/D scales interact dynamically, producing a host of different configurations. For the sake of clarity, Kwieciński adopts the terms exotisation and assimilation as complementary, yet different from foreignisation and domestication. According to Kwieciński, the latter two are strictly target-based.

Further, Kwieciński distinguishes three groups of procedures. They are as follows: a) exoticising procedures such as borrowing, calque/semantic extension/coinage (or a combination of them), b) intermediate procedures divided into rich explanatory 
categories (different combinations of exoticising procedures with intratextual or extratextual glosses) and recognised (canonical) exoticism, and finally c) assimilative procedures, for example, normalisation, deletion, covert cultural substitution, overt cultural substitution, covert/overt acculturation (Kwieciński 2004: 32-33). Drawing on his own investigation and in-depth analysis of various examples, Kwieciński shows that one can achieve instances of domesticated exoticism, foreignised exoticism or even foreignised assimilation. It may be concluded that Kwieciński tries to present a more pragmatic and less distorted image of otherness, arguing that intelligible exoticism cannot be confused with disruptive strangeness. His approach seems to respond to Ramière's doubts over the applicability of foreignisation/domestication model in practice. Ramière holds the view that, in fact, the rigid taxonomies placing certain translation procedures on one or another pole of the spectrum are highly decontextualised and thus ineffective. In her own words: "it follows that most procedures are not assimilating or exoticising in and of themselves but that these potential characteristics - if relevant at all - can only be determined in context" (Ramière 2006). Her argument leads to the statement that the translator does not decide once and for all on how they will tackle such culture-specific items, but they make a new decision for each individual item in every single act of translating. And again, as stated earlier in this paper, the translator is allowed to work as a mediator between two cultures, negotiating Self and Other from their middle-ground position (Ramière 2006). Seen in this light, the most frequent translation procedures employed in Fury will be discussed predicated on the assumption that to preserve the original allusions without hampering their target reception different shades of exoticism are the sensible approach to favour. The selection of examples was made so as to illustrate all the major translation challenges present in the novel.

\section{Case study: selected translation problems and solutions}

The first few excerpts from the novel contain names with references to music and cinema, i.e. two industries deeply rooted in American culture. The main source of the translation problems is the probable divergence between degrees of cultural relevance of certain cultural phenomena to the SC and TC audiences. Consider the following extracts from the novel together with their Polish translations:

Table 1

"Thanks to her," he raged at Eleanor, "I saw L'Année dernière à Marienbad (1a) three times in one day. [...] I'm stuck here in the blasted couloirs (1b) of French fiction and she's in a Jil Sander power suit in a fortyninth-floor corner office on Sixth Avenue [...]" (Fury, 25)

Malik Solanka, strolling alone toward a late-night Kieslowski double bill (2a) at the Lincoln Plaza, tried to imagine his own life as a Dekalog movie (2b). A Short Film
Dzięki niej - żalił się Eleanor - obejrzałem Zeszlego roku $w$ Marienbadzie trzy razy w ciągu dnia. [...] Ja tkwię tutaj w cholernych couloirs francuskiej literatury, a ona siedzi w garsonce od Jil Sander w gabinecie na czterdziestym dziewiątym piętrze biurowca przy Szóstej Alei [...] (Furia, 37)

Malik Solanka, zdążając samotnie na późny pokaz dwóch filmów Kieślowskiego w Lincoln Plaza, próbował wyobrazić sobie własne życie w filmie z cyklu Dekalog. 


\begin{tabular}{|l|l|}
\hline About Desertion. (Fury, 26) & Krótki film o porzuceniu. (Furia, 37) \\
\hline $\begin{array}{l}\text { There would be a Broadway show - she was } \\
\text { in discussion with all the major players in } \\
\text { the musical game, dear Tim and dear } \\
\text { Elton and dear Cameron and of course } \\
\text { dear, dear Andrew (3) - and a new, big- } \\
\text { budget movie was also planned. (Fury, 78) }\end{array}$ & $\begin{array}{l}\text { Miał powstać musical na Broadwayu - } \\
\text { trwał rozmowy ze wszystkimi sławami } \\
\text { Eltonem, drogim Cameronem i oczywiście } \\
\text { drogim, kochanym Andrew - planowano } \\
\text { też nowy wysokobudżetowy film. (Furia, } \\
101)\end{array}$ \\
\hline $\begin{array}{l}\text { Five-foot-nine, stacked, spoke six } \\
\text { languages, reminded everyone of Christie } \\
\text { Brinkley as the Uptown Girl (4), loved big } \\
\text { hats and high fashion, could've walked for } \\
\text { anyone Jean-Paul, Donatella, Dries had all } \\
\text { begged her... (Fury, 58) }\end{array}$ & $\begin{array}{l}\text { Metr siedemdziesiąt pięć, zmysłowe } \\
\text { kszałty, władała sześcioma językami, } \\
\text { jako Uptown Girl, uwielbiała wielkie } \\
\text { kapelusze i haute couture, mogła pracować } \\
\text { na wybiegu dla każdego - Jean-Paul, } \\
\text { Donatella, Dries, wszyscy ją błagali... } \\
\text { Furia, 75) }\end{array}$ \\
\hline
\end{tabular}

The first problem (1a) refers to a 1961 French film directed by Alain Resnais, written by an acknowledged nouveau roman author, Alain Robbe-Grillet, found controversial due to its experimental fragmentation of both temporal and spatial linearity. Although there were two official translations of the title into English, namely Last Year in Marienbad in the UK and Last Year at Marienbad in North America, in Fury it appears in its original French version. However, presumably to spare the TT readers the sense of confusion and to help them identify the film more easily, Kozłowski replaced the French title with the Polish one, Zeszłego roku $w$ Marienbadzie ('last year in Marienbad'), which might have dismissed, to a certain extent, the author's original intention. The passage in question serves to complement a description of the main protagonist's ex-wife, Sara, who out of fascination for English and French literature wrote her thesis on the French nouveau roman, whose influences marked the narrative construction of the film in question. It may be assumed that the title was left in the source text in French to foreground Sara's French bias and, at the same time, to emphasise Solanka's feeling of alienation when being with her. Given the solution adopted by the translator, this nuance seems more difficult to fully grasp when reading the target text. In the next example (1b), the author used another French term couloirs, corresponding to English 'corridors, passages'. Unlike in the first example, Kozłowski retained the ST French tinge by leaving the term untranslated in the TT. It can be argued that compared with the ST recipient, the Polish reader seems more privileged as the French borrowing kuluary ('lobby', 'backroom') has been in common usage in Polish, which obviously facilitates understanding rendering the term more transparent for the TT reader.

The second set of examples relates again to the European cinema and, more precisely, to the Polish director and screenwriter - Krzysztof Kieślowski. In Fury, the titles of his films are used to exemplify art-house intellectual cinema and might be unfamiliar to the majority of Americans, exposed mainly to their home productions. Being closer to the "cognitive base" of the author, the Polish recipient of the novel is thus 
again more privileged compared to the ST readers. The problem is therefore not so much the danger of imposing foreign elements, as finding an adequate rendition of the entire expression: a late-night Kieslowski double bill. It is indeed impossible to render equally concisely into Polish the compact English term double bill, meaning "a cinema, theatre, concert etc performance in which you can see two films, plays etc, one after the other" (Longman Dictionary of Contemporary English). Kozłowski chose to translate it as późny pokaz dwóch filmów Kieślowskiego ('a late-night screening of two Kieślowski's films'). Long as it may appear, the translation still provides a good indication of the cultural particularity in question. Next (2b), Krzysztof Kieślowski's Dekalog TV cycle is mentioned and the expression A Short Film About Desertion at the end of the extract refers clearly to the titles of two feature films from the cycle, i.e. Krótki film o miłości and Krótki film o zabijaniu and their international English equivalents, A Short Film About Love, and A Short Film About Killing. The films serve as an illustration of two biblical commandments: "thou shalt not kill" and "thou shalt not commit adultery," and in the novel A Short Film About Desertion comes to the main protagonist's mind and provokes his pangs of conscience because of abandoning his family. Yet again the allusion is clearer to the TT reader than to the ST one. This somehow reverses the ubiquitous situation with originals and translations in which the otherness is above all experienced by the TT reader.

The following excerpt (3) includes allusions to a number of musical and music celebrities. However, to suggest his ironic attitude, the narrator of Fury mentions their first names only in diminutive forms. Admittedly, the ST reader seems to have much easier a task of deciphering what famous person corresponds to each name while it may be assumed that they are much less recognisable in Poland, presumably except for Elton standing for Elton John. The rest: Tim Rice, a prominent lyricist, author of songs to, among others, Jesus Christ Superstar, Evita and the Lion King, his collaborator, Andrew Llyod Weber, a successful British composer of musicals, and Cameron Mackintosh, according to New York Time, "the most successful, influential and powerful producer (of musicals) of our time," are not at all obvious referents to an average TT reader. Therefore, in this case, the sense of the "Other" is much stronger in translation, which should not, however, entail a different, more straightforwardly "domesticating" translation strategy than the one applied by Kozłowski. He preserved the original culturespecific item and motivated an inquiring reader to trace the original links. Additionally, based on the Kwieciński's framework, it may be argued that owing to the selfexplanatory co-text (all the major players in the musical game, Fury: 78) and the context of the passage, the plain borrowing of the ST names employed in the Polish rendition without any additional glosses or intratextual explanations results indeed in "fairly domesticated exoticism" (Kwieciński 2004: 34) rather than "impenetrable and disruptive strangeness" (Kwieciński 2004: 41).

When considering the subsequent example (4), it may be reiterated that the translator's choice was to stay in line with the original content and to preserve the SC references, however illegible they might be to the Polish recipient. The example in question refers to Christie Brinkley, a symbol of American success and beauty. This American super model appeared on over 500 magazine covers around the world, had

\footnotetext{
${ }^{5}$ https://www.nytimes.com/1990/12/09/magazine/the-musical-is-money-to-his-ears.html
} 
been lending her face for 20 years to the famous in the US make-up line Cover Girl, hosted the most profitable infomercial, wrote a fitness book and even launched her own perfume. She was often labelled by the media as "an Uptown Girl" because of her appearance in the music video to Uptown Girl, a huge hit song by Billy Joel, her soon-tobe husband. This immediate connection, obvious to the ST reader, is by no means clear to the TT reader with more effort and research required on his part to decode the reference. Unlike in the source text, Kozłowski italicised the name Uptown Girl to indicate that it is some kind of a title. Regardless of the fact that this cultural link might not be easily recognisable in the target culture and retaining the name without any sort of explanation would be normally considered overt foreignisation, based on Kwieciński's approach, one may postulate that the co-text together with the italics serve as a significant explanatory tool thanks to which the translation itself becomes a "domesticated exoticism". Thus, instead of being fully incomprehensible, it becomes accessibly foreign or exotic.

Another set of examples to be quoted includes overt references to both low-brow and high-brow entertainment, abundant in the narrative of Fury.

Table 2

\begin{tabular}{|c|c|}
\hline $\begin{array}{l}\text { You still living like a guru in an ice cave? } \\
\text { Or a castaway on Big Brother is Not } \\
\text { Watching You? (5) (Fury, 111) }\end{array}$ & $\begin{array}{l}\text { Cały czas żyjesz jak guru w lodowej jaskini? } \\
\text { Albo rozbitek z jakiegoś reality show? } \\
\text { (Furia, 138) }\end{array}$ \\
\hline $\begin{array}{l}\text { This is the Oxbridge way of speech (6) } \\
(\ldots)(\text { Fury, 13) }\end{array}$ & $\begin{array}{l}\text { Mowa akademików z } \text { Oksfordu i } \\
\text { Cambridge }(\ldots)(\text { Furia }, 13)\end{array}$ \\
\hline $\begin{array}{l}\text { Malik Solanka lived in a second-floor } \\
\text { apartment in a building called Noor Ville on } \\
\text { Methwold's Estate off Warden Road (7). } \\
(\text { Fury, 65) }\end{array}$ & $\begin{array}{l}\text { Malik Solanka mieszkał w mieszkaniu na } \\
\text { piętrze w budynku Nur Ville na } \\
\text { Methwold's Estate przy Warden Road. } \\
(\text { Furia }, 84)\end{array}$ \\
\hline $\begin{array}{l}\text { (...) she preferred to quote the cartoon sex } \\
\text { bomb Jessica Rabbit. "I'm not bad," she } \\
\text { liked demurely to purr. "I'm just drawn } \\
\text { that way." (8) (Fury, 163) }\end{array}$ & $\begin{array}{l}\text { (...) wolała cytować animowaną seksbombę } \\
\text { Jessice Rabbit. „Nie jestem zla - lubiła } \\
\text { mruczeć wstydliwie - tylko ciągnie mnie } \\
\text { do tego". (Furia, 203) }\end{array}$ \\
\hline
\end{tabular}

In the first example listed in Table 2, it is surprising to see how the Polish translator substituted the ST exact reference (5) for a generic term denoting the original phenomenon, that is rozbitek $z$ jakiegoś reality show ('a castaway on some reality television show'). It should be remembered that the very idea of Big Brother rule together with the expression, "Big Brother is Watching You" comes from George Orwell's novel Nineteen Eighty-Four. The significance of words and the underlying principle of Orwell's universe - the complete surveillance over inhabitants - were transplanted a few decades later into a commercialised context constituting a base for the reality television show, Big Brother. Broadcast for the first time in the Netherlands, the programme spread to dozens of countries, including Poland. In this light, the reference in Fury could be easily preserved paraphrasing the famous one-liner "Wielki Brat patrzy" ("Big Brother is watching you') and thus fully respecting the original intention of the passage. 
The following expression, the Oxbridge way of speech (6), was used in the novel to comment on Solanka's fellow students' manner of speaking, which he himself adopted perceiving it yet as artificial and pompous. In this particular case, as much as the formal faithfulness and exact rendition of Oxbridge, standing for the universities of Oxford and Cambridge, conveys the original cultural reference, the exact wording of the Polish version might be somewhat ambiguous. Unlike the ST term, Kozłowski's rendition into mowa akademików z Oxfordu i Cambridge ('parlance of academics from Oxford and Cambridge [University]') appears rather unnatural and verbose in Polish. The use in the translation of the Polish term mowa akademików ('parlance of academics') does not convey the ST meaning referring to the way Solanka's peers used to speak. Instead, the original flow, clarity and logic of the scene has been unintentionally distorted in the target text.

The next case (7) is particularly interesting due to the twofold provenance, both real-life and fictional, of the proper names in question. Firstly, it was the author himself who grew up on Warden Road, which as a result of decolonising of names became Bhulabhai Desai Road. Secondly, Malik Solanka's boyhood address, mentioned in the extract, also coincides with yet another protagonist's home address, namely Saleem's home on Methwold's Estate off Warden Road, as featured in Rushdie's earlier novel, Midnight's Children. As a recurrent theme, Rushdie re-introduced the Warden Road setting also to his later novel, The Ground Beneath Her Feet. There is no doubt that this semi-autobiographical turned fictional setting should be preserved in the translation. The translator of Fury retained the ST address yet for a reason difficult to account for he chose to alter the original spelling of Noor Ville. His decision to retain the English Methwold's Estate seems easier to explain in the light of "foreignisation"/ "exotisation" strategy he consistently applied in his Polish rendition of the novel. It is worth mentioning, however, that in the existing Polish translation of Midnight's Children, "Methwold's Estate" is fully rendered into Polish as "Posiadłość Methwolda przy Warden Road" ('Methwold's estate/property off Warden Road') without preserving the English part of the name, i.e. estate. Therefore, on the one hand this intertextual literary allusion might be more difficult to decode for the TT reader, but on the other thanks to retaining the English proper name Kozłowski' translation aptly transmits the actual sense of the passage. Looking at the larger context, the term estate is used in Fury in its modern sense, to denote a residential area instead of "a large area of land in the country, usually with one large house on it and one owner" (Longman Dictionary of Contemporary English), as found in Midnight's Children. As in Polish it would not be possible to convey the double allusion contained in the name Methwold's Estate without breaking the logic of the passage, Kozłowski's solution seems fair.

Similarly, in the last example (8), where the lead female character of the noir comedy-thriller Who Framed Roger Rabbit, representing a hybrid genre in itself, is cited, the original reference seems distorted in the target text. Since its release in Poland in 1990, Polish TV channels have repeatedly aired the film and the sultry animated Jessica Rabbit with her femme fatale style and murmuring manner of speaking has been recognised as one of pop culture pin-up girls. In the film, she is the embodiment of both a hypersexualised film noir classic dame and her pastiche. Kozłowski’s quite infelicitous

\footnotetext{
${ }^{6}$ As translated in "Dzieci północy” (orig. "Midnight’s Children”) by Anna Kołyszko.
} 
translation of Jessica's famous catchphrase: "I'm not bad, I'm just drawn that way" into Nie jestem zła, tylko ciagnie mnie do tego ('I'm not bad, I'm just drawn to that') spoils the intended effect and misrepresents the logic behind the original culture-specific item. In the book, it is the main protagonist's head-turning wife, politically committed Neela, who resorts to quoting Jessica Rabbit to comment on people's perception of her standing in total contrast to her own moral sense. In the Polish translation of the film, the phrase was rendered, and probably well remembered by many viewers, as Nie jestem zła, tylko mnie taka rysuja ('I'm not bad, I'm just drawn that way/ they just draw me like that'). To let the ST reader track the reference and grasp the actual meaning of the passage, a more justified solution would be to use the existing and already canonical translation and keep it unaltered in the Polish version of the novel. This would also guarantee greater cohesion of the TT passage, which proves how much Neela, who purposely keeps using the quotation, is aware of her good looks and tries, perversely, to justify and distance herself from this fact.

Polyphonic diversity constitutes another hallmark of style in Fury and presents a serious challenge for the translator who ventures to preserve it as a way of respecting the source linguistic and cultural diversity. Pieczyńska-Sulik stresses that the first thing to do when attempting to render linguistic variety of individual characters is to specify their "idiolectic dominant." The best way to render this dominant is to strive for functional equivalence which, to quote the scholar, "allows freedom in cases of interlingual incongruence" (Pieczyńska-Sulik 2005: 103-106). In other words, if the target language does not offer analogous means of expression to the ones existing in the source language, the translator is obliged to reproduce the original image with the use of other language structures that are available to them. In doing so they should analyse linguistic material of a given fictional idiolect taking into consideration its recurrence. Pieczyńska-Sulik recalls that to avoid treating literary characters as puppets one has to acknowledge their autonomy and translate in accordance with the "idiolectic dominant" (2005: 115). A problem inextricably linked with the above-mentioned idiolects is stylisation of language in Fury, reflected in colloquial and slang expressions employed by several characters of the novel. This peculiar blend of styles and registers poses a serious problem for the translator willing to convey both the message and the spirit of the book. Colloquial speech and different non-standard variants of language constitute an integral part of every national language and pose one of those problems in translation to which, as many concede, there is no truly satisfactory solution. One example of such a translation challenge is shown in Table 3.

Table 3

(...) Rhinehart said, and moved into his most exaggerated Uncle Remus manner. "And now yo' ole lady she done had de same idea. She puttin' de big squeeze on him, I reckon. Gwine en' up bein' dat well-fed heifer hersel'." (9) (Fury, 112)
(...) wyjaśnił Rhinehart i zaczął naśladować sposób mówienia prostego niewolnika. A teraz twoja stara wpadla na pomysł identiko. Coś mi się zdaje, że się za niego wzięla i, dawaj, wyciskać. A że $z$ niej dobrze wypasiona jałówka, to i dopnie swego. (Furia, 140) 
The original English passage (9) includes a clear cultural link and refers to a very well-defined style of speaking. Rhinehart mimics, "the Gullah," the traditional deep southern Black dialect of Uncle Remus, fictional slave narrator of a collection of African American folktales complied in seven The Uncle Remus Tales books with animal stories, songs and oral folklore by Joel Chandler Harris. The reference was omitted in the Polish version of Fury as Kozłowski rendered his most exaggerated Uncle Remus manner into sposób mówienia prostego niewolnika ('a manner of speaking of a simple slave'). Given that in the novel there are several references to those famous tales, adapted into several featured films, retaining the intertextual link in the target text seems justified. Nevertheless, it is worth emphasising that only traces of non-standard character of the Rhinehart's manner of speaking could be reflected in the translation as according to Knauer, while the linguistic profiles of characters should be effectively retained in the TL text, the language employed to reflect the original specificity cannot be artificial nor unnatural. The scholar points out that in case of regional dialects used in the original, some translators opt for the use of the pan-Polish rural dialect. However, by doing so, they risk turning the text into an unintentionally comic and incomprehensible translation. Following this direction in translation might be both ineffective and linguistically unjustified and, the most important is that it could not pass the test for the authenticity and cultural competence (Knauer 1996: 88-92).

When analysing the translation of the excerpt in Table 3, it might be argued that Kozłowski tried to avoid this trap by mirroring, at least to a certain degree, the ST use of careless pronunciation and non-standard constructions, without resorting to the excessively rural Polish, or any other particularly strong and instantly recognised dialect, such as the Silesian or the highland dialect. As Knauer (1996: 87) rightly points out, such "false domestication" of the foreign language makes the Polish reader perceive it from the angle of their own emotional attitude towards some Polish dialects and this defeats the purpose of translation.

Although some might suggest that the existent translation of the passage could be improved and more suitable equivalents found, one has to realize that whatever linguistic tools are to be applied to convey the original content and spirit with reference to different idiolects present in the original text, the final outcome would always be its imperfect imitation devoid of the cultural flavour of the original.

\section{Concluding remarks}

As articulated with force by many theoreticians of translation, including Mary SnellHornby, Susan Bassnett, André Lefevere, or Tomislav Z. Longinovic, in the age of growing hybridisation of cultures, translations have to be adjusted to expectations of contemporary readership. Balancing deftly the domestic and the foreign in order to bring cultures closer constitutes one of primary obligations of today's translator aspiring to produce a valuable target text. Since the author of Fury is considered to be the "other" voice in English literature, being, in his own words, a multinational hybrid drawing on rich eastern and western traditions, the analysed novel abounds in various cultural references, which determines the culture-oriented approach the translator of the text is obliged to adopt. To achieve his/her goal and succeed in initiating a cultural dialogue, 
$\mathrm{s} /$ he must act as a mediator who benefits from his/her extensive knowledge of the ST and the TT culture and language, individual experience and awareness of available strategies and methods to decide what elements of the original text should be retained and what could be modified and how the entire process of negotiating the degree of otherness introduced into the translated text, both in terms of its form and content should be managed.

The above selections of excerpts from Fury together with their Polish translations exemplify numerous instances of the ST culture-specific content that could possibly hamper the reception of the target text. In many cases in the Polish translation of Fury, the multilayered character of the original has been preserved in the translation thanks to conscious decisions taken by the translator. To deal with the culture-loaded items in the source text, Jerzy Kozłowski sought to respect the cultural unfamiliarity by preserving the traces of the unknown without resolving to "disruptive strangeness", to quote Kwieciński's concept. Examples cited in the paper prove that even in those instances when the task of mirroring the source connotations in the target text is not fully accomplished thus rendering the ideal of equal reception unreachable, the co-text, larger context and the very awareness of the reader can facilitate the understanding of cultural references to a great extent. As a result, the strangeness the target reader is exposed to often becomes "domesticated exoticism".

Nevertheless, as illustrated in the paper, in some passages eliciting similar response in the target reader proved an unattainable goal. Not all the original references could be tracked, occasionally intertextuality tends to be lost and the source linguistic and stylistic playfulness is no longer there, as it is often the case with translations of books inscribing themselves in the discourses of our contemporary culture. To some extent, the original spirit of the text is always more or less sacrificed for the sake of obtaining a coherent text that follows the inherent rules and limitations of the target language. Still translation driven by the cultural approach proves the most sensible choice as it allows for acquainting the contemporary TT reader with a great deal of novelty, which constitutes an intrinsic feature of an enriching cultural dialogue. The Polish rendition of Fury is one of many examples of contemporary translations which demonstrate that the cultural turn in translation is not a purely theoretical whim of translation scholars but actual response to the TT reader's willingness to get acquainted with the cultural specificity of the original and to explore it on their own terms.

\section{References}

Bassnett, S. \& Lefevere, A. (eds). 1990. Translation, History and Culture. London: Pinter.

Bhabha, H. 1994. The Location of Culture. London and New York: Routledge.

Di Mauro, L. (ed.) 1990. Modern British Literature, Volume III. Detroit: St James Press.

Hatim, B. 2001. Teaching and Researching Translation. Essex: Pearson Education Limited.

Katan, D. M. 1996. The translator as cultural mediator. Quaderno 96 Programma 'Sociologia Internazionale, Istituto di Sociologia Internazionale di Gorizia, 1-19. 
Knauer, K. 1996. Między kompetencją lingwistyczną a kulturową. Tłumaczenie odmian angielskiego na podstawie przekładu powieści Alice Walker The Colour of Purple. In: P. Fast (ed.), Polityka a przekład, 85-93. Katowice: Wydawnictwo Śląsk.

Kwieciński, P. 2004. Between Conventional Exoticism and Impenetrable alterity. A Tentative Descriptive Framework. In: O. Kubińska, \& W. Kubiński (eds.), Przekładajac nieprzekładalne 2, 29-42. Gdańsk: Wydawnictwo Uniwersytetu Gdańskiego.

Longman Dictionary of Contemporary English (Fifth Edition). 2009. Harlow: Pearson Education Limited.

Pieczyńska-Sulik, A. 2005. O przydatności kategorii idiolektu w przekładzie; Na materiale Wróżb kumaka Güntera Grassa. In: J. Koźbiał (ed.), Recepcja, Transfer, Przekład 3. Oblicza recepcji, 103-115. Warszawa: Wydawnictwo UW.

Ramière, N. 2006. Reaching a foreign audience: Cultural transfers in audiovisual translation. The Journal of Specialised Translation 6: 152-166.

Rushdie, S. 2002. Furia. Poznań: Dom Wydawniczy REBIS.

Rushdie, S. 2002. Fury. London: Vintage Books.

Snell-Hornby, M. 1990. Linguistic transcoding or cultural transfer: a critique of translation theory in Germany. In: S. Bassenett, \& A. Lefevere (eds.). Translation, History and Culture, 79-86. London: Pinter.

Tokarz, B. 2006. Przekład w dialogu międzykulturowym. In: F. Piotr, \& P. Janikowski (eds.). Dialog czy nieporozumienie? Z zagadnień krytyki przekładu, 7-20. Katowice: Wydawnictwo Śląsk.

Urbanek, U. 2010. Tłumaczenie jako komunikacja interkulturowa. In: S. Grucza, A. Marchwiński, \& M. Płużyczka (eds.). Translatoryka. Koncepcje Modele Analizy, 156163. Warszawa: Wydział Lingwistyki Stosowanej UW.

Woods, T. 2005. Postcolonial Fictions. In: L. Marcus, \& P. Nicholls (eds.), The Cambridge History of Twentieth Century English Literature, 736-750. Cambridge University Press.

Agnieszka Stawecka-Kotuła works as an assistant lecturer at Maria Curie-Skłodowska University in Lublin, Poland. She holds an MA degree in Applied Linguistics in English and French from Maria Curie Skłodowska University in Lublin, and an MA degree in French Studies from The John Paul II Catholic University of Lublin, where she is currently working towards a $\mathrm{PhD}$. She also completed a master's degree program (Master 1) in Specialised Translation and Language Engineering (French and English) at Paris Diderot University. Her research interests centre on translation, intercultural communication, and contrastive linguistics. 